\section{> Gjesteskribent}

\section{Audun Farbrot}

Fagsjef, forskningskommunikasjon ved Handelshøyskolen BI (@afarbrot på Twitter)

\title{
Si det med 140 tegn
}

\section{All kommunikasjon starter med de første 140 tegn. Det er resepten for å konkurrere med sex og lavkarbo om medienes oppmerksomhet.}

Helse er godt stoff, og havner ikke så rent sjelden på forsidene av avisene, enten de nå kommer ut på papir eller nett. Helsesaker er også blant avisenes mest leste saker. Og det er ikke så rart.

Helse er personlig relevant for de aller fleste lesere - det angår oss selv, noen i familien, venner eller noen andre vi kjenner.

Men det er ikke alltid slik at antall spaltemeter $\mathrm{i}$ avisene avspeiler viktigheten av et tema. Noen ganger kan det se ut som om størrelsen på oppslaget er omvendt proporsjonal med betydningen av en sak. Og det er heller ikke alltid slik at tabloidoverskriften holder hva den lover.

Jeg er for lengst mett på artikler om lavkarbodietter, som til og med skal ha fått oss til å fly mann og kvinne av huse for å proviantere bacon og smør i kilovis.

Konkurransen om medienes oppmerksomhet er blitt stadig tøffere. Det blir ikke noe enklere av at den utspiller seg i stadig nye kanaler.

Sex selger. Det gjør (fortsatt) også lavkarbo. Og ny forskning om at kaffe er sunt eller usunt. Eller vin som forlenger livet eller forårsaker helseskader. Eller om «løsningen» på kreftgåten. Eller om enkeltpersoners hjerterå møte med sykehus og helsevesen.

Hva er det som skal til for å nå frem med nyansert kunnskap og råd om viktige emner som ikke helt når opp i kioskveltersjangeren? Hvordan komme på trykk med en kronikk eller et debattinnlegg? Hvordan engasjere og få ditt publikum til å høre på og tenke over hva du sier?

Forskere og fagfolk må gjøre kunnskap om komplekse sammenhenger personlig relevant for den de skriver for eller snakker til. Uten at de trenger å ofre fagligheten. Det er leseren, seeren, lytteren eller samtalepartneren som bestemmer om hun vil høre på deg. Det handler om å ramme inn budskapet slik at mottakeren kjenner seg igjen i temaet du presenterer.

Du har ikke så mye tid på deg for å vekke interesse og engasjement hos ditt publikum. Stadig færre har tålmodighet til å følge deg på hele den lange reisen til dine gullkorn og gode poenger.

Om du ikke lykkes med å tenne gnisten og interessen hos leseren eller ditt publikum på 140 tegn, har du antageligvis tapt. Du kommer ikke på trykk. Du blir ikke lest. Du blir ikke hørt. Og da hjelper det ikke hvor vesentlig eller viktig ditt anliggende er - om du da ikke treffer noen av vår tids siste tålmodige sjeler.

Så kan det jo fortone seg som ekstremsport å presentere kunnskap om kompliserte sammenhenger på 140 tegn, et format definert av mikrobloggtjenesten Twitter. Er det i det hele tatt mulig å si noe av en viss faglig og akademisk verdi i form av én setning eller to? En typisk vitenskapelig artikkel teller mellom 3000 og 8000 ord. Ganger du med en faktor på rundt 6 . får du antall tegn. For en fagbok snakker vi fort vekk om 80000 ord.

Tenk deg at du plutselig møter Aftenpostens innflytelsesrike kultur- og debattredaktør Knut Olav Åmås i heisen. Du har en sak du mener Aftenposten burde se nærmere på - som vil være av stor interesse for Aftenpostens lesere. Heisen er i bevegelse. Du har en mulighet til å vekke redaktørens nysgjerrighet og få til en avtale om å ta kontakt. Hva sier du? Rekker du å si det?

Dette er en situasjon der det ikke er så dumt å hente inspirasjon fra amerikanske nettverksbyggere som trener på å utvikle effektive appeller på 30-60 sekunder med betegnelsen «elevator pitch». En passende norsk oversettelse ville kunne være «døråpner».

Det er selvfølgelig grenser for hva det er mulig å si på 140 tegn. Men det går faktisk an å åpne en dør som gir deg mulighet til å nå frem med budskapet ditt i alle sine nyanser. Klarer du å vekke interessen, møter du en leser eller et publikum som er motivert til å tenke grundigere gjennom det du har å si.

Det er ikke enkelt, men fullt ut mulig å ta opp konkurransen med både lavkarbo og sex.

Her er noen praktiske råd: Gå rett på sak, og si det viktigste først. Gjør det relevant og tilgjengelig for den du skriver for eller snakker til. Da må du også være nysgjerrig på ditt publikum. Vær konkret og poengtert. Bruk et enkelt og forståelig norsk - vær gjerne frisk, frodig, elegant og personlig. Vær for all del ikke kjedelig, selv om du snakker om alvorlige temaer.

«A forme ord er en storslagen virksomhet. Ord kan skape broer. Men de kan også skape sperrer,» skriver samfunnsforskeren Nils Christie.

Du kan skape din bro til oppmerksomhet gjennom de 140 første tegn.

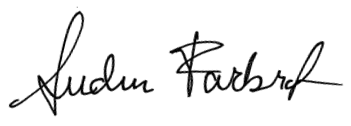

